\title{
Examining host-State counterclaims for environmental damage in investor-State dispute settlement from human rights and transnational public policy perspectives
}

\section{Ted Gleason ${ }^{1}$}

Accepted: 20 November 2020 / Published online: 14 December 2020

(c) The Author(s), under exclusive licence to Springer Nature B.V. part of Springer Nature 2020

\begin{abstract}
In international disputes between investors and host-States, the traditionally asymmetric nature of international investment agreements (IIAs) may prevent States from bringing claims against investors for harm caused, including environmental damage. At the same time, allowing host-State counterclaims for environmental damage is a potentially useful tool for rebalancing the asymmetric nature of IIAs. Yet, in the highly fragmented area of international investment law, the availability of host-State counterclaims is not always clear. This article analyses the procedural and legal bases available for host-State counterclaims for environmental damage, including newly developing human rights and transnational public policy approaches to such claims. The question that this article seeks to evaluate is to what extent host-State counterclaims are available to rebalance the asymmetric relationship between host-States and investors, specifically concerning environmental damage. To answer this question, the article takes a qualitative approach by examining case law, commentary, and the work of international organizations, and applying the results of the research to the specific context of host-State counterclaims for environmental damage. Future developments are also discussed in the context of ongoing multilateral investorState dispute settlement reform efforts at the United Nations Commission on International Trade Law. There currently exists a window of opportunity for States to seek cooperative, effective multilateral strategies for partially rebalancing the relationship between investment and the environment. The article posits that harmonization of State approaches towards counterclaims for environmental damage is desirable and States should take a permissive approach towards host-State counterclaims for environmental damage in their IIA treaty negotiation practice.
\end{abstract}

Keywords Investor-State dispute settlement (ISDS) - International investment agreements (IIAs) $\cdot$ Counterclaims $\cdot$ Environmental damage $\cdot$ Human rights

Ted Gleason

ted.gleason@grenoble-em.com

1 Department of Gestion, Droit, Finance, Grenoble Ecole de Management, Grenoble, France 


\section{Introduction}

International investment law is often perceived to be in conflict with other important societal goals, including environmental protection. Typically, investors who believe that they have been aggrieved by host-State conduct can use International Investment Agreements ('IIAs'), whether bilateral investment treaties ('BITs') or multilateral agreements, which include the Investor-State Dispute Settlement ('ISDS') mechanism, to bring an arbitration claim against the host-State outside of that State's judicial system. These agreements have traditionally been asymmetric in nature, meaning that they impose obligations on hostStates, but not investors who accrue rights thereunder. This asymmetry has been described as being '[h]ardwired into the very structure of investment treaties' (Kryvoi 2012, p. 218). Practically speaking, this creates a situation under international law whereby States have legal obligations towards qualified foreign investors, while those same investors do not necessarily have reciprocal obligations towards host-States. This has contributed to the perception that ISDS is by nature one-sided in favour of foreign investors to the detriment of host-States (Kalicki 2013). The asymmetric nature of IIAs can act as a barrier to counterclaims against investors using ISDS, even where an investor causes significant harm to the host-State, including environmental damage. This is a result of international investment law having given investors a privileged position and is evidence of States favouring investment and trade over other important societal matters and concerns, including the environment (Douglas 2013, p. 416).

The perceived imbalance between investors and host-States in this field has led to public outcry in various contexts. ${ }^{1}$ The paradigm of foreign investment has shifted as many private parties now have more economic resources than many States (Boeckstiegel 2007, p. 95). By way of example, in 2018, the 500th company on the Forbes Global 500 list had more yearly revenue than the nominal GDP of 72 countries (Fortune Global 5002018 ; World Bank GDP 2018). Moreover, and perhaps more importantly, traditionally capitalexporting States who shaped contemporary investment law have increasingly found themselves on the receiving end of investor claims under various IIAs. As a result, States have increased scrutiny of ISDS, and are currently examining reform options in a multilateral setting. In 2017, the United Nations Commission on International Trade Law ('UNCITRAL') established Working Group III ('WGIII') with a broad mandate concerning ISDS reform, whose work is ongoing.

The reform efforts are timely. Foreign-direct-investment has been on the decline in recent years for a variety of reasons (WIR 2019, p. 3), and proponents of ISDS and international investment law must be willing to reform to preserve. As highlighted by Angel Gurría, Secretary General of the OECD, '[i]f we want things to stay as they are, things will have to change,' and such changes cannot be superficial (Gurría 2017). The United Nations Conference on Trade and Development ('UNCTAD') has recognized that ' $t$ the investment dispute settlement system must be designed to produce just outcomes that are viewed as reflecting key societal values' (Issues Note 1 2019, p. 27). This requires State action. In line with UNCTAD's approach, and in the current climate of ISDS reform, State action needs to be directed towards balancing investor rights with support for other important societal goals. One potentially impactful way to do this is for States to authorize limited

\footnotetext{
1 E.g., the German public's opposition to the Vatenfall v. Germany case concerning nuclear power production, and opposition to the Philip Morris cases against both Australia and Uruguay.
} 
counterclaims through their treaty drafting practice (Bjorklund 2013, p. 466). Counterclaims can allow a host-State to enforce obligations on an investor, including environmental obligations (Kjos 2007, p. 7). Increasing the availability of counterclaims, particularly in the context of environmental damage, could achieve greater balance between the rights of States and investors by creating a more equal and efficient system for ISDS (Kryvoi 2012, p. 218).

Additionally, leading scholars have called on WGIII to address asymmetry in ISDS as part of reform efforts (Issues Note 12019 , p. 21). In particular, the missing framework for host-State counterclaims has been identified as an area deserving reform efforts (WGIII 2020 , p. 3). ${ }^{2}$ Yet, it remains unclear to what degree States will agree to discuss host-State counterclaims. WGIII discussions may focus only on procedural elements of ISDS, or may venture into substantive discussions concerning the legal basis for counterclaims and obligations to be imposed on investors relating to human rights, the environment, compliance with domestic law, etc. (Ibid., pp. 40, 41). What is clear is that ISDS is at a crossroads, and a window of opportunity currently exists. Foreign-investment and environmental protection have the possibility to move from being potentially conflicting to potentially supportive realities (Viñuales 2010, p. 6), and States have a chance to put environmental considerations on equal footing with trade and investment concerns.

This article seeks to explore to what extent host-State counterclaims can rebalance the relationship between States and investors in the specific context of environmental damage. It takes a qualitative approach to answering this question by first examining case law and scholarly commentary concerning host-State counterclaims generally; and then more specifically by surveying additional relevant materials (cases, commentary, and documents from the UN System) regarding counterclaims based on domestic and international law, respectively. The results of this research are then applied to the particular context of environmental damage caused by investors in host-States, through both human rights, and transnational public policy lenses. As such, the article first outlines the general legal basis for counterclaims in treaty-based ISDS, highlighting the current fragmented approach existing in international law. Then it will focus on the patchwork of possible legal bases of counterclaims for environmental damage, specifically examining counterclaims from emerging human rights and transnational public policy perspectives. Finally, the article will focus on future developments in this rapidly changing area of law and provide suggestions concerning the harmonization of approaches concerning this issue in light of the ongoing multilateral reform discussions at UNCITRAL.

\section{Availability of host-State counterclaims in treaty-based ISDS}

Investment law is highly fragmented as there are thousands of treaties protecting investment in force in the world today. As a fundamental matter, ISDS requires consent of the disputing parties to use the mechanism, however, ' $[t]$ here is no room for general sweeping statements about whether counterclaims are within the consent to arbitrate investor claims' (Lalive and Halonen 2011, p. 7.26). The language of arbitration agreements in IIAs is not homogenous, and it is this language that determines whether consent to counterclaims

\footnotetext{
2 Scheduled for discussion during WGIII's 39th session from 30 March-3 April 2020, postponed to October 2020 due to COVID-19.
} 
exists (Kjos 2007, pp. 14, 19). Even if host-State counterclaims are within the parameters of the parties' consent, the enquiry does not end there. Counterclaims must also be based on obligations owed by the investor to the host-State founded in law that the Tribunal has the authority to apply (Lalive and Halonen 2011, pp. 7.18, 7.23). Accordingly, the availability of host-State counterclaims under the current state of international investment law can only be examined on a case-by-case basis.

Nonetheless, some generalities can be observed. Importantly, the two main procedural frameworks governing ISDS, ICSID and UNCITRAL Arbitration Rules, both allow counterclaims as long as they are within the jurisdiction of the Tribunal. Yet, the simple inclusion of ICSID or UNCITRAL Rules in an IIA is not sufficient to indicate consent to host-State initiated counterclaims. Under both frameworks, parties can derogate from the general rule that counterclaims are permissible. It is therefore essential to understand how the agreement permitting disputes to be submitted to ISDS proceedings defines the types of disputes subject to arbitration.

Even where host-State counterclaims are authorized by both procedural rules and the parties' language of consent, some arbitral decisions have constructed an additional barrier to counterclaims, focusing on whether the counterclaims are closely affiliated with the investor's underlying claims (Bjorklund 2013, pp. 473-474). This has been described as the connectedness requirement, or connexion (Kjos 2007, p. 5). Case law offers no uniform view concerning how connexion is met, and there is doctrinal debate concerning whether a factual connection ${ }^{3}$ between the investor's claims and the host-State's counterclaims is sufficient, or whether there needs to be a legal nexus ${ }^{4}$ as well (Lalive and Halonen 2011, pp. 7.40-7.41; Atanasova et al. 2014, p. 387). One of the first publicly known investment arbitration awards comprehensively addressing the availability of host-State counterclaims was Saluka v. Czech Republic. The broad treaty language granting jurisdiction to 'all disputes...concerning an investment' in conjunction with the UNCITRAL Rules was found to allow counterclaims in principle (Saluka, p. 39). Yet the counterclaims were not admitted since the Tribunal found mere factual connexion to be insufficient, requiring legal connexion as well (Ibid., pp. 78, 79). Various subsequent cases followed this approach. A notable example is Paushok v. Mongolia, where the Tribunal rejected a counterclaim for 'violation of environmental obligations' for lack of a legal connexion as it related to Mongolian legislation and regulation and not the applicable treaty (Paushok, pp. 678, 696).

The Saluka approach is problematic for host-States who have suffered damage caused by an investor. Under an asymmetrical IIA the host-State will be hard-pressed to identify a legal basis for counterclaims within the IIA itself, for environmental damage or otherwise. That is not to say that investors do not have legal obligations to host-States, however counterclaims for environmental damage are most often based on domestic environmental law, not IIAs. Despite procedural rules authorizing counterclaims generally, the Saluka line of cases indicates that unless there is express language in the operative treaty allowing for application of host-State domestic law, domestic law will not form a valid basis for admissible counterclaims since the requisite legal connexion would be missing. This renders environmental counterclaims virtually impossible under most circumstances and has been criticized by various authors as too demanding (Kjos 2007, p. 46; Lalive and Halonen 2011, pp. 7.41-7.42; Douglas

\footnotetext{
3 That the investor's claims and host-State's counterclaims are based on the same facts.

4 That the investor's claims and host-State's counterclaims are based on the same law, e.g., a BIT.
} 
2013, pp. 430-431; Atanasova et al. 2014, p. 383) and 'makes the apparent availability of counterclaims a mirage' (Lalive and Halonen 2011, p. 7.40).

Nevertheless, a preponderance of recent cases suggests that legal connexion is not necessary (Hussin 2019, p. 6) indicating that tribunals are moving away from this requirement. For example, the Goetz v. Burundi Tribunal unanimously found a factual nexus between the claims brought by the investor and the counterclaims brought by the State to be sufficient (Goetz, pp. 282-285). As the applicable BIT permitted claims to be resolved based on the BIT, as well as national and international law, when read in conjunction with the ICSID regime it was interpreted as authorizing counterclaims (Ibid., pp. 276-281). More recently, in Urbaser v. Argentina, the investors objected to Argentina's counterclaims based on the asymmetric nature of the operative BIT. However, the Tribunal found that the BIT's dispute resolution clause containing neutral language clearly indicated that a factual connection between the original and counterclaims was sufficient to take jurisdiction over the counterclaims (Urbaser, p. 1151). It recognized that while '[i]t is certain and undisputable that the BIT's main and manifestly prevailing focus is on a number of standards of protection for the investors rights and interests... there is no provision stating that the...host-State would not have any rights under the BIT' (Ibid., pp. 1183-1184).

Doctrinal approaches have also evolved. Zachary Douglas has discerned a general principle from the practice of various international tribunals that the subject matter jurisdiction of an international tribunal 'extends to counterclaims unless expressly excluded by the constitutive instrument' (Douglas 2013, p. 427). While this 'express exclusion' approach has by no means been uniformly adopted (Atanasova et al. 2014, pp. 386-387), the approach is very much a deviation from the Saluka line of cases, and a welcome development for advocates of allowing host-State counterclaims for environmental damage.

Moreover, there is growing evidence that arbitral practice is moving in a more permissive direction concerning host-State counterclaims for environmental damage in particular. ISDS tribunals are not immune from the global shift towards increased awareness on environmental issues (Hussin 2019, p. 10) and have recently identified the importance of reconciling the at times seemingly disparate areas of foreign direct investment and environmental law. Counterclaims for environmental damage were recently granted in the related cases of Perenco v. Ecuador and Burlington v. Ecuador. Notably, the Perenco Tribunal stated:

Proper environmental stewardship has assumed great importance in today's world.

The Tribunal agrees that if a legal relationship between an investor and the State permits the filing of a claim by the State for environmental damage caused by the investor's activities and such a claim is substantiated, the State is entitled to full reparation in accordance with the requirements of the applicable law. (Interim Decision on Counterclaims, p. 34)

Nevertheless, whether counterclaims are permissible remains a grey area depending on many legal factors (Atanasova et al. 2014, p. 358). The Perenco Tribunal recognized the fragmented nature of this field of law as it qualified its decision to grant full reparation to Ecuador by stating that this is generally possible only if 'the legal relationship between the investor and the State permits filing' of a counterclaim for environmental damage (Interim Decision on Counterclaims, p. 34). Unless and until there exist multilateral efforts clarifying the availability of counterclaims in ISDS generally, this lack of clarity will persist. 


\section{Possible legal bases of counterclaims for environmental damage in treaty-based ISDS}

Even where procedurally permissible, host-State counterclaims for environmental damage are only effective if based on legal obligations owed by the foreign investor to the hostState. Once the applicable law subject to the Tribunal's mandate is determined, the hostState must point to an obligation owed by the foreign investor based on that law. Careful analysis of the operative agreement is required to determine whether claims can be made under (a) the IIA only, (b) the IIA alongside customary international law, (c) the IIA, customary international law and domestic law, or (d) some other combination of applicable laws. The importance of this issue cannot be understated since a breach of legal obligations by the investor will often be based on domestic, rather than international law, which may not be subject to ISDS depending on the relevant treaty language.

\subsection{Legal obligations based on host-State domestic law}

Thus, the question arises, when can domestic law form the basis of host-State counterclaims? Due to the fragmented nature of international investment law, the answer is that classic legal answer of 'it depends'. With broad treaty language and factually connected claims, domestic legal obligations should be permitted as the legal bases of such claims (Douglas 2013, pp. 424, 433, 442-443; Lalive and Halonen 2011, pp. 7.32-7.33). For example, wording such as 'all disputes relating to the investment' would likely support counterclaims based on domestic environmental law (Viñuales 2010, p. 19). Naturally, this is also the case when a treaty expressly references the domestic law of the host-State as being applicable, as in Goetz, or where an investor does not contest that a tribunal is the appropriate forum for resolution of the counterclaims as was the case in Burlington and Perenco. Where domestic law is applicable, a tribunal may need to resort to expert testimony from local legal experts concerning application of domestic environmental laws. This is not problematic per se as investment arbitration tribunals regularly rely on such experts appointed by the parties when examining complicated issues of local law.

On the other hand, a treaty may contain a narrowly drafted applicable law provision restricting a foreign investor's obligations to those found in the operative treaty, if any. In such cases, there is no realistic avenue for counterclaims based on host-State domestic law to be successful. As an asymmetrical IIA typically imposes no obligations on a foreign investor, the substantive legal base for such claims will be lacking. Examples of such narrowly tailored language can be found in the Energy Charter Treaty ${ }^{5}$ and the former NAFTA. ${ }^{6}$ That is not to say that domestic environmental law is completely irrelevant in such circumstances, however, domestic laws and investor compliance would be issues of fact, not law. (Ibid.)

Additionally, treaty language is not always clear concerning the issue of applicable law. For example, an IIA may have no express language concerning the applicable substantive law. Here, reference to the governing procedural rules is useful. ICSID Convention Art. 42(1) states that where parties failed to agree on applicable law, 'the Tribunal shall apply the law of the Contracting State party to the dispute... and such rules of international law as

\footnotetext{
5 Art. 26(1).

6 Arts. 1116 and 1117.
} 
may be applicable.' UNCITRAL Rules Art. 35 provides that where parties fail to designate applicable law, 'the arbitral tribunal shall apply the law which it determines to be appropriate.' In both situations it is possible that host-State environmental laws could form the basis of counterclaims, if a factual connexion to the investor's claims is present. Such situations must be addressed on a case-by-case basis.

\subsection{Legal obligations based on international law}

Treaty language permitting, international law may provide a separate basis for host-State counterclaims. This leads to an additional question concerning which sources of international law impose international legal obligations on foreign investors. Treaties and customary international law, for environmental protection or otherwise, generally impose obligations directly on States, not private parties. Nevertheless, there are various international legal obligations which can potentially be imposed upon investors.

\subsubsection{Counterclaims based on human rights obligations}

Since IIAs give investors the right to invoke international legal instruments, the question arises whether such investors can conversely be subject to obligations under international law, including human rights obligations. In this context, the Urbaser Award is notable for its consideration of a host-State counterclaim concerning the human right to water. It rejected the notion that 'corporations are by nature not able to be subjects of international law and therefore not capable of holding obligations' (Urbaser, p. 1194). The Tribunal reasoned that since corporations have rights under international law, they may also have obligations. Specifically, 'international law accepts corporate social responsibility as a standard of crucial importance for companies operating in the field of international commerce...it can no longer be admitted that companies operating internationally are immune from becoming subjects of international law' (Ibid., p. 1195). Moreover, the operative BIT's broad wording permitted the Tribunal to determine that it was not 'to be construed as an isolated set of rules of international law for the sole purpose of protecting investments through rights exclusively granted to investors' (Ibid., pp. 1188, 1189). Instead, the BIT was interpreted in light of relevant rules of international law applicable in the relations between the parties, including those relating to human rights (Ibid., pp. 1200, 1201). Accordingly, the Tribunal cited Art. 25(1) ${ }^{7}$ and Art. $30^{8}$ of the Universal Declaration of Human Rights ('UDHR'), Art. 5(1) of the International Covenant on Economic, Social and Cultural Rights ('ICESCR'), ${ }^{9}$ and the International Labor Office's Tripartite Declaration of Principles concerning Multilateral Enterprises and Social Policy to support the conclusion that there is an obligation on all parties, public and private, not to engage in activities aimed at destroying the human rights of others (Ibid., pp. 1196, 1199).

\footnotetext{
7 'Everyone has the right to a standard of living adequate for the health and well-being of himself and of his family, including food, clothing, housing and medical care and necessary social service'.

8 'Nothing in this Declaration may be interpreted as implying for any State, group or person any right to engage in any activity or to perform any act aimed at the destruction of any of the rights and freedoms set forth herein.'

9 'Nothing in the present Covenant may be interpreted as implying for any State, group or person any right to engage in any activity or to perform any act aimed at the destruction of any of the rights or freedoms recognized herein, or at their limitation to a greater extent than is provided for in the present Covenant.'
} 
Nevertheless, private parties are not subject to the same international legal obligations as States, thus, a host-State must identify as a particular cause of action the specific international law obligations imposed upon a private party (Ibid., p. 1206). The Urbaser Tribunal made an important distinction between an obligation to perform and an obligation to abstain. It highlighted that a State's obligation to perform certain acts transfers to investors through a contractual framework subject to domestic, but not international law (Ibid., p. 1210). To the contrary, obligations to abstain from committing acts violating human rights under international law can apply to both States and private parties (Ibid.). Argentina's human rights obligation to provide drinking water and sanitation services was an obligation to perform and transferred to the investor via contract, not international law. Thus, the Tribunal could not find an independent human rights obligation of the investor sourced in international law that corresponded to Argentina's obligation to provide water and sanitation (Schacherer 2018, p. 30). The counterclaim consequently failed.

As Urbaser engaged in a novel approach to the role of human rights in the ISDS context, it is not without its criticisms. Patrick Abel's analysis of the case argues that the Tribunal's reasoning was obscure (Abel 2018, pp. 68,72). He takes issue with the conclusion that corporations can have human rights obligations arguing that international law has not arrived at this conclusion (Ibid., p. 83). His position is that corporations can only have non-binding 'responsibilities', and the Tribunal conflated non-binding human rights norms with legally binding human rights obligations (Ibid., pp. 77-79). Edward Guntrip argues that Article 30 UDHR and Article 5(1) ICESCR are self-containing and aimed at preventing the deliberate misinterpretation of one human rights obligation found in each respective document to justify the violation of other rights found therein (Guntrip 2017). He contends that a general obligation to abstain is not clearly established by these provisions, since based on a restrictive interpretation they do not apply to rights sourced from other treaties (Ibid.).

Despite these disagreements, in the relatively short time since Urbaser, at least one other tribunal has been convinced to follow the approach in part. Aven v. Costa Rica relied on Urbaser for the proposition that while it is primarily to States to enforce environmental law, "it cannot be admitted that a foreign investor could not be subject to international law obligations in this field, particularly in the light of (the broad treaty language of the applicable IIA)' (Aven, p. 737). The Tribunal further opined:

This Tribunal shares the views of Urbaser Tribunal that it can no longer be admitted that investors operating internationally are immune from becoming subjects of international law. It is particularly convincing when it comes to rights and obligations that are the concern of all States, as it happens in the protection of the environment.' (Ibid., p. 738).

Nevertheless, Costa Rica did not prevail on its counterclaims. First, the Tribunal stated that the articles of the IIA upon which Costa Rica based its counterclaims did not 'in and of themselves - impose any affirmative obligations on investors' (Ibid., p. 743). In other words, Costa Rica failed to base its counterclaim on international law obligations of the investor. Whether this impliedly adopted the Urbaser approach juxtaposing an affirmative obligation to perform with a negative obligation to abstain is not clear. The Tribunal did not engage in this analysis, likely because Costa Rica also failed to make adequate factual allegations, thus contributing to the failure of the counterclaims (Ibid., p. 745).

Similarly, in his Partial Dissenting Opinion in Bear Creek Mining v. Peru, Philippe Sands cited Urbaser for the notion that even though a convention may not impose obligations directly on a private party investor, this does not mean that it is without legal effects for the investor (Partial Dissenting Opinion, p. 10). Sands directly quoted Urbaser 
concerning the obligation of private parties not to engage in activity aimed at destroying human rights and highlighted that a BIT 'has to be construed in harmony with other rules of international law of which it forms part, including those relating to human rights' (Ibid. citing Urbaser, pp. 1199, 1200). He then used this reasoning to invoke ILO Convention $169,{ }^{10}$ stating:

This Tribunal is entitled to take the Convention into account in determining whether the Claimant carried out its obligation to give effect to the aspirations of the Aymara peoples in an appropriate manner, having regard to all relevant legal requirements, including the implementing Peruvian legislation (Ibid., p. 11). ${ }^{11}$

Under Article 15 of ILO Convention 169, indigenous people have a right to participate in the use, management and conservation of natural resources. Ultimately, Professor Sands found that the Claimant did not fully allow local communities to exercise legitimate interests and rights in their land, ${ }^{12}$ failed to engage in proper community relations, and did not provide an adequate opportunity for members of certain communities to participate in essential consulting processes (Ibid., pp. 35, 36). The dissenting opinion did not explicitly differentiate between whether the rights at issue were based on obligations to perform or abstain. Yet, that the Claimant prevented, or at least did not allow, legitimate rights and interests to be exercised can properly be construed as a failure to abstain from destroying the rights of others, and conforms with the Urbaser approach.

Since ISDS cases are heavily dependent on the language of the operative IIA along with the factual circumstances of the case, and ultimately the interpretation of the Tribunal seized, no general conclusions can be derived concerning whether human rights obligations can be imposed on an investor in a given case. Nevertheless, a roadmap is present. The Urbaser line of cases opens the door to human rights-based host-State counterclaims and the obligation to abstain from activities aimed at destroying human rights may provide a cause of action for environmental damage caused by an investor in ISDS proceedings. Should States find the approach to be desirable, ongoing multilateral discussions are capable of defining the parameters of human rights-based counterclaims and clarifying how and when they may be used in future investor-State disputes.

\subsubsection{Counterclaims for environmental damage based on human rights obligations}

In Urbaser, the specific human right at issue was the right to water, officially recognized as a human right by the UN in 2010 (Resolution 64/292). However, unlike the right to water, there is as of yet no expressly recognized universal international human right to a safe, clean, healthy, and sustainable environment ('right to a healthy environment'). While the ongoing work of the UN Human Rights Council Special Rapporteur on Human Rights and the Environment ('Special Rapporteur') may lead to recognition of such a right in some form, the international community has not expressly arrived at this point. This does

\footnotetext{
10 Indigenous and Tribal Peoples Convention 1989.

11 Importantly, the applicable law clause of the operative IIA provided that the Tribunal shall decide the issues in dispute in accordance with this Agreement and applicable rules of international law' allowing for ILO Convention 169 to be taken into consideration as a rule of international law applicable to Peru. See Partial Dissenting Opinion at p. 11.

12 E.g., participating in the use, management, and conservation of natural resources, as well as participating in the benefits of the investment project.
} 
not indicate that human rights and environmental protection are disparate areas of law, in fact, the contrary is the case. Since at least the Stockholm Declaration of 1972 there has been international recognition of the link between human rights and environmental protection and it has been 'firmly established...that environmental degradation can and does adversely affect the enjoyment of a broad range of human rights' (Knox 2013, p. 17). Additionally, 155 States have recognized the right to a healthy environment in some form, and there have been consistent recommendations in recent years that the right be globally recognized as fundamental. (Knox and Boyd 2018, p. 36; UN Experts 2019).

Moreover, the Special Rapporteur recently outlined that all States, including those yet to recognize the right to a healthy environment, have obligations as set out by the Framework Principles on Human Rights and the Environment ('Framework Principles') (Boyd 2019, p. 8). Said principles do not create new obligations, '[r]ather, they reflect the application of existing human rights obligations in the environmental context.' (Knox 2018, p. 8). Yet, in many cases, resort to non-binding concepts such as those elaborated by the principles will not be required in practice. Once again, fragmentation prevails. As more than $80 \%$ of UN Member States legally recognize the right to a healthy environment in some form (Boyd 2019, p. 13), a universally recognized right will often not be necessary to form the basis of a host-State counterclaim against a private party to abstain from destroying that right. Whether a legally recognized right to a healthy environment exists as the basis for a host-State counterclaim must be determined on a case-by-case basis by looking at the host-State's human rights obligations found in regional agreements and national law (Knox 2018, p. 11).

Still, until the right to a healthy environment is fully recognized by the international community, where there is doubt concerning whether the right exists, a host-State counterclaim may be better grounded in other discrete human rights concepts implicated in the context of environmental damage. Under the Urbaser approach, a cause of action may be based on allegations that the investor failed to abstain from engaging in activity aimed at destroying some other recognized human right, thus leading to environmental damage. Examples of such rights include environmental threats to the right to the enjoyment of the highest attainable standard of physical and mental health, ${ }^{13}$ and the right to an adequate standard of living and its components ${ }^{14}$ (Knox 2013, pp. 20, 21). The 2018 Framework Principles acknowledged this 'greening' of existing human rights, but at the same time favoured explicit recognition of the right to a healthy environment, arguing that it raises the profile and importance of environmental protection. (Framework Principles 2018, pp. 12-14). It remains to be seen whether the international community will follow this call to action.

\subsubsection{The role of transnational public policy}

Should a host-State find it difficult to base a potential counterclaim for environmental damage on domestic legal obligations or international human rights approaches, transnational public policy may provide an additional path for such claims. Transnational public policy refers to generally accepted fundamental international principles across legal systems that

\footnotetext{
13 E.g., improper disposal of toxic waste, exposure to radiation and harmful chemicals, oil pollution, and large-scale water pollution.

14 E.g., improper use of pesticides as a threat to the right to food, waste from extractive industries infringing the right to water.
} 
are part of the public policy of a majority of States (Kreindler 2015, p. 10; Lew 2018, pp. 25-26). It consists of norms relating to a range of issues, from maintenance of international public order to incorporating into law universal moral or ethical foundations linked to the survival of our species (Gowlland-Debbas 2011, p. 245). Further, it signifies an international consensus accepted by 'civilized nations' that must be applied (Lew 2018, p. 22). Such consensus is not demonstrated using any singular source but rather through various sources, including international convention law, national law, arbitral case law, general principles of law, scholarly writings, and customs and usages (Jagusch 2015, pp. 29, 32; Kreindler 2015, pp. 10-11; Lew 2018, pp. 22, 30). Unanimity is not required (Ibid.), however, the principles should be 'largely recognized by the international community' (Lew 2018, pp. 22-23). Convergence of national laws on a particular point is a strong indicator that transnational public policy exists (Jagusch 2015, p. 29), as is convergence between various sources in addition to national laws (Lew 2018, pp. 27-28). Rather than consisting of a list of discrete principles, it is perhaps best viewed as a method that examines a combination of sources to determine its existence in specific circumstances (Ibid., pp. 29, 32). 'Which rule or principle should be applied in a particular case will depend on the facts and the way in which the arbitral tribunal "sees" the case at the relevant time' (Hunter and Conde e Silva 2003, p. 369).

Application of transnational public policy in ISDS as a general matter is not novel (Jagusch 2015, p. 45). A well-known example is World Duty Free v. Kenya where the Tribunal expressly applied transnational public policy against bribery and corruption (World Duty Free, p. 157). In the context of transnational public policy, there is clearly consensus that corrupt behaviour is prohibited (Kreindler 2015, pp. 10-11). Consensus exists despite divergent approaches between jurisdictions and international legal instruments concerning important issues such as how an arbitral tribunal determines that actions are corrupt (Lew 2018, pp. 34-35, 39). The World Duty Free Tribunal found consensus by looking to the national law of many countries, numerous international conventions, and arbitral jurisprudence (World Duty Free, p. 141 et seq; Jagusch 2015, p. 35). It noted that since transnational public policy demonstrates international consensus, norms considered transnational public policy are applicable in all fora (World Duty Free, pp. 139, 141; Lew 2018, p. 58).

The World Duty Free approach towards transnational public policy can be transposed to human rights and environmental damage. Despite divergent approaches between national and international legal instruments concerning human rights and the environment, consensus concerning various fundamental rules, principles, and norms can be observed. The Special Rapporteur identified this consensus and established that a great majority of countries have recognized the right to a healthy environment at the national or regional level, while simultaneously acknowledging a 'greening' of other human rights principles by treaty bodies, regional tribunals, and other special rapporteurs (Framework Principles 2018, pp. 11-13).

The rationale behind treating principles concerning human rights and the environment as transnational public policy is clear. Both human rights and environmental law have principles and rules of a fundamental character whose binding force is derived from their underlying rationale and relevance for protection of fundamental global interests (Gowlland-Debbas 2011, p. 246). Accordingly, it should be generally accepted that such principals have a role in international arbitration (Jagusch 2015, p. 45). Giving effect to such policy in ISDS proceedings is fundamentally logical. ISDS tribunals are capable of advancing 
transnational public policy concerning human rights, ${ }^{15}$ and simultaneously the environment, ${ }^{16}$ by enforcing such policy in the context of environmental damage (Miles and Nichols 2017, p. 126; World Duty Free, pp. 142-157). Transnational public policy upholding minimum standards of conduct accepted in most countries concerning environmental damage and human rights does not conflict with trade and investment, rather it increases predictability and stability. Thus, the question arises, in the context of a host-State counterclaim for environmental damage, what transnational public policy is relevant? While this is dependent on the specificities of a given case, it could take various forms.

The first concerns the responsibility of private parties under international law. The principle that corporations themselves have a responsibility to respect human rights is one of the pillars of the normative framework which applies to environmental human rights abuses (Knox 2013, p. 59). While this responsibility has been described as a moral rather than legal obligation, international law is clearly moving towards imposing human rights obligations on private parties, and transnational public policy is arguably already there. Special Rapporteurs Knox and Boyd recognized in their 2018 joint report that, in line with the UN Human Rights Council Guiding Principles on Business and Human Rights ('Guiding Principles') businesses have a responsibility to avoid causing or contributing to adverse human rights impacts through environmental harm (Knox and Boyd 2018, p. 18). Guidelines, recommendations, and other instruments created by international organizations can form part of transnational public policy 'because they have been widely accepted by different societies around the world' (Kessedjian 2007, p. 861). Furthermore, Framework Principle 12 states that 'States should ensure the effective enforcement of their environmental standards (which may be derived from international legal obligations) against public and private actors', and as the official commentary clarifies, States should punish and redress violations of environmental standards by private parties (Framework Principles 2018, p. 34). The Urbaser line of cases further evidences this movement towards holding private parties responsible as subjects of international law under certain circumstances. While some commentators may disagree with this approach, convergence of a variety of sources on this point is taking place, and a line of cases recognizing that private parties can be subjects of international law is developing in the ISDS sphere.

Second, there is a pertinent question concerning whether the principle that private parties must abstain from destroying rights of others can be considered transnational public policy. Despite criticisms of the Urbaser Tribunal's reasoning on this issue, its approach is in line with the Guiding Principles. The Principles articulate a fundamental principle that 'business enterprises... should avoid infringing on the human rights of others' and 'requires that business enterprises... [a]void causing or contributing to adverse human rights impacts through their own activities.' (Guiding Principles 2011, p. 11). While these principles have been said to consist of non-binding responsibilities of corporations, their language imply obligation, and in addition to the transnational public policy indicating that private parties can be subject to international law obligations, evidences growing consensus that, quite simply, corporations must not violate human rights. The commentary to Framework Principle 12 echoes the approach found in the Guiding Principles stating that 'the responsibility of business enterprises to respect human rights includes the responsibility to avoid causing

\footnotetext{
15 As reflected by myriad sources, e.g., the International Bill of Rights, Guiding Principles on Business and Human Rights, the Revised Draft, regional instruments, and the work of the UN Human Rights Council.

16 As reflected by, e.g., the Stockholm and Rio Declarations, the work of the Special Rapporteur, myriad international environmental law treaties, and the law of 155 countries.
} 
or contributing to adverse human rights impacts through environmental harm.' (Framework Principles 2018, p. 35). Similarly, the UN's revised draft Treaty on Business and Human Rights ('Revised Draft') underlines in its Preamble that 'all business enterprises...have the responsibility to respect all human rights, including by avoiding causing or contributing to adverse human rights impacts through their own activities...' While this instrument is still in its early stages, the international community is clearly moving towards upholding this policy.

Third, while there is no multilateral legal instrument formally recognizing a right to a healthy environment, transnational public policy has also developed in this context. The right enjoys wide recognition by States combined with numerous international conventions concerning affirming the right. Again, 155 States have recognized the right to a healthy environment in some form. An additional 36 States have signed non-binding international declarations explicitly incorporating the right. Thus, of 193 UN member States, only Oman and North Korea have not expressed support for the right to a healthy environment. (Knox and Boyd 2018, pp. 34, 36). Additionally, arbitral jurisprudence has consistently underlined the importance of environmental protection. Despite multilateral foot dragging in developing a formal right to a healthy environment, the international consensus surrounding this issue indicates the existence of applicable transnational public policy. Ongoing ISDS reform efforts provide an additional opportunity to expand on this consensus, as well as define the extent to which transnational public policy can be used in ISDS proceedings.

\section{Future developments: towards defragmentation?}

As outlined above, proponents of ISDS must engage in non-superficial reforms in an effort to preserve the system to the extent possible. From an environmental protection standpoint the current fragmented, case-by-case basis approach to the availability of host-State counterclaims for environmental damage is undesirable and inefficient. Regulation of business enterprises to protect against human rights abuses resulting from environmental harm is of paramount importance, and remedies for such abuses need to be available (Knox and Boyd 2018, p. 17). One such remedy may be increased use of host-State counterclaims for environmental damage in ISDS proceedings. While counterclaims are not a panacea, they are considered by UNCTAD to be an 'Improved ISDS Procedure' and form part of the reform toolkit for rebalancing of the asymmetrical nature of ISDS (Issues Note 1 2019: Box 1). In evaluating foreign investment projects, many governments, especially those who rely heavily on foreign investment for development, may not have the technical capacity to identify potential human rights abuses and environmental damage until after the fact (Boyd 2020, p. 22). The availability of host-State counterclaims for environmental damage in ISDS could serve a balancing function in such situations. Furthermore, the specter of counterclaims could potentially have an important deterrent effect on bad behaviour. Still, while the window is currently open for cooperative multilateral reforms, enabling hostState counterclaims remains one of the least frequent procedural reforms included in recent IIAs (Issues Note 1 2019, Box 1, Table 4; 10). The question remains whether ongoing UNCITRAL reform efforts could lead to a uniform approach in this regard, and if so, what would it look like?

As treaty language and arbitral jurisprudence provide little uniformity concerning host-State counterclaims for environmental damage, the most effective way to allow such claims is through systemic reform to treaty practice. 'This could take the form either of 
interpretative notes about existing treaty text, or more likely the negotiation of specific provisions about counterclaims in new treaties' (Kalicki 2013). Should States so desire, there are few barriers to including clauses permitting host-State counterclaims for environmental damage in the new generation of IIAs. In fact, there has been a clear trend in treaty practice towards including environmental clauses in IIAs in recent years (Viñuales 2016, p. 14; Hussin 2019, p. 4). Practically speaking however, for there to be any semblance of consistency and harmonization, an approach clarifying the availability of host-State counterclaims under existing treaties needs to be simultaneously developed. The majority of ISDS cases are under old-generation IIAs where the availability of counterclaims may not be clear. Of the 71 known treaty-based ISDS cases initiated in 2018, all but one were under treaties signed before 2012 (Issues Note 2 2019, p. 3). If reform is piecemeal and only addresses new-generation IIAs, this could have the adverse effect of creating additional fragmentation, uncertainty, and complexity in an already murky area of the law (Issues Note 12019 , p. 26). Therefore, modernizing old-generation treaties remains a priority and 'so far such reform actions have addressed a relatively small number of IIAs...(thus) there is broad scope and urgency to pursue them further' (Issues Note 32019 , pp. 4, 8).

Should States find it desirable, procedural reform of new and existing treaties should expressly authorize host-State counterclaims. Innovative treaty language could make it clear that when an investor accepts a host-State's offer to arbitrate found in an IIA, it is also consenting to the host-State being able to bring a claim against it. In other words, IIAs could give investors the choice to consent to host-State counterclaims or relinquish their rights under the agreement. This would work to rebalance the asymmetry found in old-generation IIAs by avoiding situations whereby an investor can bring claims against a host-State while being insulated from its own wrongdoing in the ISDS sphere. Concerning the substantive elements of IIAs, treaty practice can be modernized to expressly impose obligations linked to domestic environmental obligations upon investors. Regarding newly negotiated treaties, treaty language must simply require that investors follow domestic environmental laws and regulations. For old-generation IIAs, amendments are capable of expressly clarifying whether violation of domestic environmental obligations could provide a valid cause of action upon which a host-State could base a counterclaim.

Treaty practice can also be modernized concerning international norms. As environmental concerns have hitherto been sidelined in favour international economic cooperation, integration of environmental norms into international economic agreements is necessary to prevent them from continued relegation in this context (Sands 2003, p. 53). States regularly use language in investment contracts requiring investors to follow domestic legal obligations as well as international norms (Douglas 2013, pp. 434-435), and the contractual practice should be extended to treaty practice. A potential solution for both old-generation and new treaties is to reference relevant global standards. Doing so would avoid the thorny issue of whether obligations found outside of the four corners of an IIA should be integrated therein, as the obligations would then originate in, or at a minimum be incorporated by reference, in the agreement itself (Abel 2018, p. 83). In addition to the aforementioned Framework Principles and Guiding Principles, reference could be made to the UN Charter, the Universal Declaration of Human Rights, UN Global Compact, OECD Guidelines for Multinational Enterprises, and UN 2030 Agenda for Sustainable Development (Issues Note 32019 , p. 6). There is evidence that this practice has begun to take root, as voluntary standards and guidelines have started to appear in new-generation IIAs, generally in the 
context of corporate social responsibility (Lahlou et al. 2019). ${ }^{17}$ Thus, for the advocate of increasing the availability of host-State counterclaims for environmental damage the way forward is for States to engage in treaty practice that expressly allows counterclaims based on domestic law as well as international norms. This requires harmonization of State approaches as well as clear applicable law clauses in IIAs.

While modifying each existing treaty may be overly cumbersome, interpretive notes may provide an additional way forward. Multilateral cooperation (perhaps under the auspices of WGIII) and development of common interpretations of regularly recurring language found in old-generation IIAs could be a novel, but useful way to achieve this. Such interpretations could allow States to harmonize positions concerning various issues such as:

(a) Whether counterclaims can be based on host-State domestic environmental laws and regulations;

(b) Whether, and to what extent human rights obligations can be imposed on investors;

(c) Whether there is a general right to a healthy environment;

(d) Whether, and to what extent transnational public policy can be used in ISDS proceedings.

Another important issue concerns situations where the foreign investor owning an investment in a host-State is protected by the corporate veil from lability for environmental damage caused by its investment. If the local entity in the host-State caused the damage, the question arises as to whether the corporate veil should be pierced to hold a shareholding entity from the investor-State responsible. An in-depth analysis of this important issue is beyond the scope of this article, but as with other concerns regarding host-State counterclaims, issues concerning corporate veil protection when investments have caused environmental damage could also be resolved by treaty language and/or interpretive notes should States so desire. Whether States move in this direction remains to be seen, however, the Revised Draft, as well as the Guiding Principles indicate movement towards holding parties responsible, ${ }^{18}$ despite complex business relationships and structures, for transnational human rights violations (Revised Draft 2019, Art. 6; Guiding Principles 2011, Arts. 13, 14).

\section{Conclusion}

Due to the fragmented nature of investment law, determining whether host-State counterclaims for environmental damage are available in ISDS proceedings can feel comparable to wandering through a labyrinth. Nevertheless, this article has highlighted emerging human rights and transnational public policy bases for host-State counterclaims for environmental damage. As demonstrated above, trends indicate that more permissive approaches towards allowing such claims where they are factually connected to the underlying claims and not

\footnotetext{
17 Examples include the EFTA-Indonesia CEPA (2018) and the Canada-EU CETA (2016).

18 If counterclaims for environmental damage succeed, questions concerning appropriate remedies arise. While this issue is beyond the scope of this article, remedies will generally need to be addressed taking the factual elements of a dispute into consideration, in order to determine whether primary (i.e., preventative or restorative) or secondary (i.e., pecuniary damages) remedies are most appropriate.
} 
outside the parties' consent are prevailing. Still, even where tribunals allow counterclaims, host-States often struggle to ground claims on obligations owed by investors founded on law that the tribunal has the authority to apply. Where claims based on domestic environmental law are unavailable, the emerging human rights-based approach to host-State counterclaims for environmental damage may provide adequate grounds. Moreover, transnational public policy arguments, while yet to be tested in this specific context, may provide additional grounds for environmental counterclaims. In the end however, it is States who shape ISDS, and should States wish to harmonize their approaches and balance the inherent asymmetry of the procedure by uniformly authorizing factually connected counterclaims, they may engage in treaty practice which achieves this. Furthermore, the FDI landscape is not fixed. As development increases, so does the competition between states to attract investment alongside the heterogeneity of FDI projects. Even if available, competing political interests and other factors may steer countries away from pursuing counterclaims. Nevertheless, with the ongoing ISDS reform providing a forum, there presently exists an important opportunity for increased discussions concerning the asymmetric nature of ISDS alongside investment law's relationship with environmental and other societal issues. Whether States ultimately take up their rights remains to be seen.

\section{Author's contribution}

I declare that I solely drafted the work, critically revised it for important intellectual content, approved the version to be published, and agree to be accountable for all aspects of the work in ensuring that questions related to the accuracy or integrity of any part of the work are appropriately investigated and resolved.

\section{References}

Abel, P. (2018). Counterclaims based on international human rights obligations of investors in international investment arbitration: Fallacies and potentials of the 2016 ICISD Urbaser v. Argentina Award. Brill Open Law, 1(1), 61-90.

Atanasova, D., Martínez Benoit, C. A., \& Ostřanský, J. (2014). The legal framework for counterclaims in investment treaty arbitration. Journal of International Arbitration, 31(3), 357-391.

Bjorklund, A. K. (2013). The role of counterclaims in rebalancing investment law. Lewis and Clark Law Review, 17(2), 461-480.

Boeckstiegel, K.-H. (2007). Enterprise v. State: The New David and Goliath? Arbitration International, 23(1), 93-104.

Boyd, D. R. (2019). Right to a healthy environment: good practices: Report of the Special Rapporteur on the issue of human rights obligations relating to the enjoyment of a safe, clean, healthy and sustainable environment, United Nations General Assembly, Human Rights Council, Forty-third session, Doc. A/ HRC/43/53, 30 December 2019. Available at: https://undocs.org/en/A/HRC/43/53.

Boyd, D. R. (2020). Good practices of States at the national and regional levels with regard to human rights obligations relating to the environment: Summary Report of the Special Rapporteur on the issue of human rights obligations relating to the enjoyment of a safe, clean, healthy and sustainable environment, United Nations General Assembly, Human Rights Council, Forty-third session, Doc. A/ HRC/43/54, 23 January 2020. Available at: https://undocs.org/A/HRC/43/54.

Douglas, Z. (2013). The enforcement of environmental norms in investment treaty arbitration. In P. M. Dupuy \& J. Viñuales (Eds.), Harnessing foreign investment to promote environmental protection (pp. 415-444). Cambridge: Cambridge University Press.

Fortune Global 500. (2018). Available at https://fortune.com/global500/2018/search/.

Gowlland-Debbas, V. (2011). An emerging international public policy. In U. Fastenrath, et al. (Eds.), Bilateralism to community interest: Essays in honour of Judge Bruno Simma (pp. 241-256). Oxford: Oxford University Press.

Gross Domestic Product. (2018). Available at https://databank.worldbank.org/data/download/GDP.pdf 
Guntrip, E. (2017). Urbaser v. Argentina: The Origins of a Host State Human Rights Counterclaim in ICSID Arbitration?. EJIL: Talk!, February 10, 2017, available at https://www.ejiltalk.org/urbaser-v-argentinathe-origins-of-a-host-state-human-rights-counterclaim-in-icsid-arbitration/

Gurría, A. (2017). Globalisation: Don't Patch It Up, Shake It Up, 6 June 2017, available at http://www. oecd.org/fr/presse/globalisation-do-not-patch-it-up-shake-it-up.htm, citing Giuseppe Tomasi di Lampedusa's novel Il GattIssopardo.

Hunter, M., \& Conde e Silva, G. (2003). Transnational public policy and its application in investment arbitrations. The Journal of World Investment, 4(3), vii-378.

Hussin, A. (2019). Environmental counterclaims under the CPTPP: Lessons for Asia from recent investorstate jurisprudence. Transnational Dispute Management 16(5).

International Labour Organization (ILO). (1989). Indigenous and tribal peoples convention, C169, 27 June 1989, C169.

Jagusch, S. (2015). Issues of substantive transnational public policy. In: Bray, D., Bray, H. L. (Eds.), International arbitration and public policy. Juris: pp. 23-48.

Kalicki, J. (2013). Counterclaims by states in investment arbitration. Investment Treaty News, January 14, 2013, Available at https://www.iisd.org/itn/2013/01/14/counterclaims-by-states-in-investment-arbit ration-2/

Kessedjian, C. (2007). Transnational Public Policy. In: Albert Jan van den Berg (Ed.), International Arbitration 2006: Back to Basics?, ICCA Congress Series Vol. 13, pp. 857-870.

Kjos, H. E. (2007). Counterclaims by host states in investment treaty arbitration. Transnational Dispute Management 4.

Knox, J. H. (2013). Report of the independent expert on the issue of human rights obligations relating to the enjoyment of a safe, clean, healthy and sustainable environment: Mapping report, United Nations General Assembly, Human Rights Council, Twenty-Fifth Session Doc A/HRC/25/53, 30 December 2013. Available at https://undocs.org/en/A/HRC/25/53.

Knox, J. H. (2018). Report of the Special Rapporteur on the issue of human rights obligations relating to the enjoyment of a safe, clean, healthy and sustainable environment, United Nations General Assembly, Human Rights Council, Thirty-seventh session, Doc. A/HRC/37/59, 24 January 2018. Available at https://undocs.org/A/HRC/37/59 (Framework Principles on Human Rights and the Environment)

Knox, J. H., \& Boyd, D. R. (2018). Report of the special rapporteur on the issue of human rights obligations relating to the enjoyment of a safe, clean, healthy and sustainable environment, United Nations General Assembly, Seventy-third session, Doc. A/73/188,19 July 2018. Available at https://undoc s.org/A/73/188.

Kreindler, R. (2015). Standards of procedural international public policy. In: Bray, D., \& Bray, H. L. (Eds.), International arbitration and public policy. Juris, pp. 9-22.

Kryvoi, Y. (2012). Counterclaims in investor-state arbitration. Minnesota Journal of International Law, 21(2), 216-252.

Lahlou, Y., Willard, R., \& Craven, M. (2019). The rise of environmental counterclaims in mining arbitration. In: The guide to mining arbitrations-First Edition, Global Arbitration Review. Available at https ://globalarbitrationreview.com/chapter/1194145/the-rise-of-environmental-counterclaims-in-minin g-arbitration

Lalive, P., \& Halonen, L. (2011). On the availability of counterclaims in investment treaty arbitration. Czech Yearbook of International Law, pp. 141-156.

Lew, J. D. M. (2018). Transnational public policy: Its application and effect by international arbitration tribunals. In: Conferencia Hugo Grocio, Fundacion Universitaria San Pablo CEU, Available at http:// www.idee.ceu.es/Portals/0/CIAMEN/Hugo\%20Grocio\%202016.pdf?ver=2018-07-12-141009-723

Miles, W. J., \& Nichols, S. K. (2017). Climate change and dispute resolution. Dispute Resolution International, 11(2), 117

Sands, P. (2003). Principles of international environmental law. Cambridge: Cambridge University Press.

Schacherer, S. (2018). International investment law and sustainable development: Key cases from the 2010 s. In: Bernasconi-Osterwalder, N., \& Dietrich Brauch, M. (Eds.), International institute for sustainable development. Available at https://www.iisd.org/sites/default/files/publications/investment-lawsustainable-development-ten-cases-2010s.pdf

United Nations. (1969). Vienna Convention on the Law of Treaties, 23 May 1969, United Nations Treaty Series, Vol. 1155, p. 331,

United Nations Commission on Trade and Development. (2019). World Investment Report: Special Economic Zones. UNCTAD/WIR/2019, available at https://unctad.org/en/PublicationsLibrary/wir2019_ en.pdf ("WIR")

United Nations Commission on Trade and Development. (2019). IIA Issues Note-International Investment Agreements-March 2019 Issue 1; Reforming Investment Dispute Settlement: A Stocktaking, 
UNCTAD/DIAE/PCB/INF/2019/3, available at https://unctad.org/en/PublicationsLibrary/diaepcbinf 2019d3_en.pdf ('Issues Note 1').

United Nations Commission on Trade and Development. (2019). IIA Issues Note-International Investment Agreements-May 2019 Issue 2; Fact Sheet on Investor-State Dispute Settlement Cases in 2018, UNCTAD/DIAE/PCB/INF/2019/4, available at https://unctad.org/en/PublicationsLibrary/diaepcbinf 2019d4_en.pdf ('Issues Note 2').

United Nations Commission on Trade and Development. (2019). IIA Issues Note-International Investment Agreements-June 2019 Issue 3; Taking Stock of IIA Reform: Recent Developments, UNCTAD/DIAE/ $\mathrm{PCB} / \mathrm{INF} / 2019 / 5$, available at https://unctad.org/en/PublicationsLibrary/diaepcbinf2019d5_en.pdf ('Issues Note 3').

United Nations General Assembly Resolution 64/292, 28 July (2010). Available at https://www.un.org/en/ ga/search/view_doc.asp?symbol=A/RES/64/292.

United Nations Human Rights Council. (2019). Open-Ended Intergovernmental Working Group on Transnational Corporations and Other Business Enterprises with Respect to Human Rights, Revised Draft Legally Binding Instrument to Regulate, In International Human Rights Law, the Activities of Transnational Corporations and Other Business Enterprises, 16 July 2019, available at https://www.ohchr.org/ Documents/HRBodies/HRCouncil/WGTransCorp/OEIGWG_RevisedDraft_LBI.pdf ('Revised Draft')

United Nations Human Rights Office of the High Commissioner (2011). Guiding principles on business and human rights, HR/PUB/11/04, 2011, available at https:/www.ohchr.org/documents/publications/ GuidingprinciplesBusinesshr_eN.pdf

United Nations Human Rights Office of the High Commissioner (2019). Failing to protect biodiversity can be a human rights violation-UN Experts, 25 June 2019, Available at https://www.ohchr.org/EN/ NewsEvents/Pages/DisplayNews.aspx?NewsID=24738\&LangID=E ('UN Experts')

Viñuales, J. E. (2010). Foreign investment and the environment in international law: An ambiguous relationship. Centre for International Environmental Studies Research Paper No. 02, forthcoming in British Yearbook of International Law 80.

Viñuales, J. E. (2016). Foreign investment and the environment in international law: The current state of play. C-EENRG Working Papers, University of Cambridge. https://repository.graduateinstitute.ch/recor $\mathrm{d} / 294734 ? \ln =$ en

Working Group III (Investor-State Dispute Settlement Reform) (2020).Possible reform of investor-State dispute settlement (ISDS): Multiple proceedings and counterclaims, Note by the Secretariat, United Nations General Assembly, United Nations Commission on International Trade Law: Working Group III (Investor-State Dispute Settlement Reform), Thirty-ninth session, Doc. A/CN.9/WG.III/WP.193, 22 January 2020. Available at: https://undocs.org/A/CN.9/WG.III/WP.193 ('WGIII')

\section{Cases}

Aven et al v. Republic of Costa Rica, Award of the Tribunal, Case No. UNCT 15/318, September 2018.

Burlington Resources Inc. v. Republic of Ecuador, Decision on Ecuador's Counterclaims, ICSID Case No. ARB/08/5, 7 February 2017.

Goetz v. Burundi, Award, ICSID Case No. ARB/01/2, 21 June 2012.

Inceysa Vallisoletana, S.L v. Republic of Ecuador, Award, ICSID Case No. ARB/03/26, 2 August 2006.

Perenco Ecuador Ltd. v. Ecuador, ICSID Case No. ARB/08/6, Interim Decision on Counterclaims, 11 August 2015.

Perenco Ecuador Ltd. v. Ecuador, ICSID Case No. ARB/08/6, Award, 27 September 2019.

Paushok et al v. Mongolia, Award on Jurisdiction and Liability, 28 April 2011.

Saluka Investments B.V. v. Czech Republic, Decision on Jurisdiction over Czech Republic's Counterclaim, 7 May 2004.

Urbaser et. al. v. The Argentine Republic, Award, ICSID Case ARB/07/26, 8 December 2016.

World Duty Free Company Limited v. The Republic of Kenya, Award, ICSID Case No. ARB/00/7, 4 October 2006.

Publisher's Note Springer Nature remains neutral with regard to jurisdictional claims in published maps and institutional affiliations. 